\title{
APPLICATION OF PRODUCTION GEOCHEMISTRY FOR NEW EXPLORATION OF THE CICUCO- BOQUETE-VIOLO AREA: COLOMBIA
}

\author{
Antonio Rangel*1, Santiago González*2 and Claudia Posada ${ }^{3}$ \\ ${ }^{1}$ Ecopetrol S.A. - Instituto Colombiano del Petróleo, A.A. 4185 Bucaramanga, Santander, Colombia \\ ${ }^{2}$ Ecopetrol S.A. - Gerencia Centro Oriente, El Centro, B/bermeja, Santander, Colombia \\ ${ }^{3}$ Ecopetrol S.A. - Vicepresidencia de Producción, Gerencia Técnica, Bogotá, Colombia \\ e-mail: arangel@ecopetrol.com.co e-mail:sagonzal@ecopetrol.com.co
}

(Received 16 June 2003; Accepted 30 October 2004) and opportunities for new explorations in the area.

As for reservoir connectivity, the Momposina and Boquilla fields are not connected among themselves or to the Cicuco-Boquete fields and the Cicuco-Boquete oils seem constitute various subgroups, indicating stratigraphic and/or structural discontinuities inside their reservoirs.

The Ciénaga de Oro Formation is the main source rock in the area and their extracts show correlation with crude oils from the Cicuco-Boquete fields. As for the pathway of migration related to the Ciénaga de Oro Formation, the generation zone can be divided in at least three areas, related to the two main faulting tendencies. These are four different migration routes related to the accumulations of: 1) Cicuco-Boquete; 2) Momposina-1 ; 3) Ayombe-1 and Guepajé-1; and, 4) Apure-1 and Apure-2X.

Regarding new exploration opportunities, it is suggested that structures located along the migration route be evaluated, especially those structures along the migration pathway.

Keywords: reservoir continuity, migration pathways, oil generation.

* To whom correspondence may be addressed 
ste estudio involucra la evaluación geoquímica de veintiocho (28) pozos del área Cicuco-Boquete y su integración con la información geoquímica disponible de estudios regionales con el propósito de establecer la continuidad del yacimiento, inferir dirección de migración y posibilidades de reexploración del área.

En cuanto a la conectividad de los campos Momposina y Boquilla, estos hacen parte de estructuras diferentes, no interconectadas entre. Los crudos de los campos Boquete y Cicuco forman subgrupos que indican discontinuidades estratigráficas y/o estructurales.

La Formación Ciénaga de Oro es la roca fuente principal del área y muestra correlación con los crudos de los Campos Cicuco-Boquete. En cuanto a las rutas de migración asociadas con la Formación Ciénaga de Oro, la zona de generación está compartimentalizada por las dos tendencias principales de fallamiento del área, originando por lo menos cuatro rutas de migración de diferente orientación asociadas a las acumulaciones o manifestaciones de crudo de: 1) Cicuco-Boquete; 2) Momposina-1; 3) Ayombe-1 y Guepajé-1; y 4) Apure-1 y Apure-2X.

Respecto a nuevas oportunidades de exploración se propone la posibilidad de 4 nuevas áreas prospectivas ubicadas a lo largo de las 4 rutas de migración propuestas en este trabajo.

Palabras claves: continuidad del yacimiento, rutas de migración, generación del crudo. 


\section{INTRODUCTION}

The Lower Magdalena Valley Basin (LMVB) is a frontier basin located in the northern part of Colombia, in which the Plato Sub-basin, and the Cicuco-BoqueteViolo fields are located (Figure 1).
Several characterization and regional hydrocarbonsource rock evaluation studies have been carried out in the area (Chevron, 1986; Amoco, 1990; Martínez, 1994; Esri-Ilex, 1995; Cenpes-Petrobras, 1996; Rangel et al., 1999). Nevertheless, the knowledge about petroleum processes, reservoir geochemistry and petroleum system characteristics is minimal.

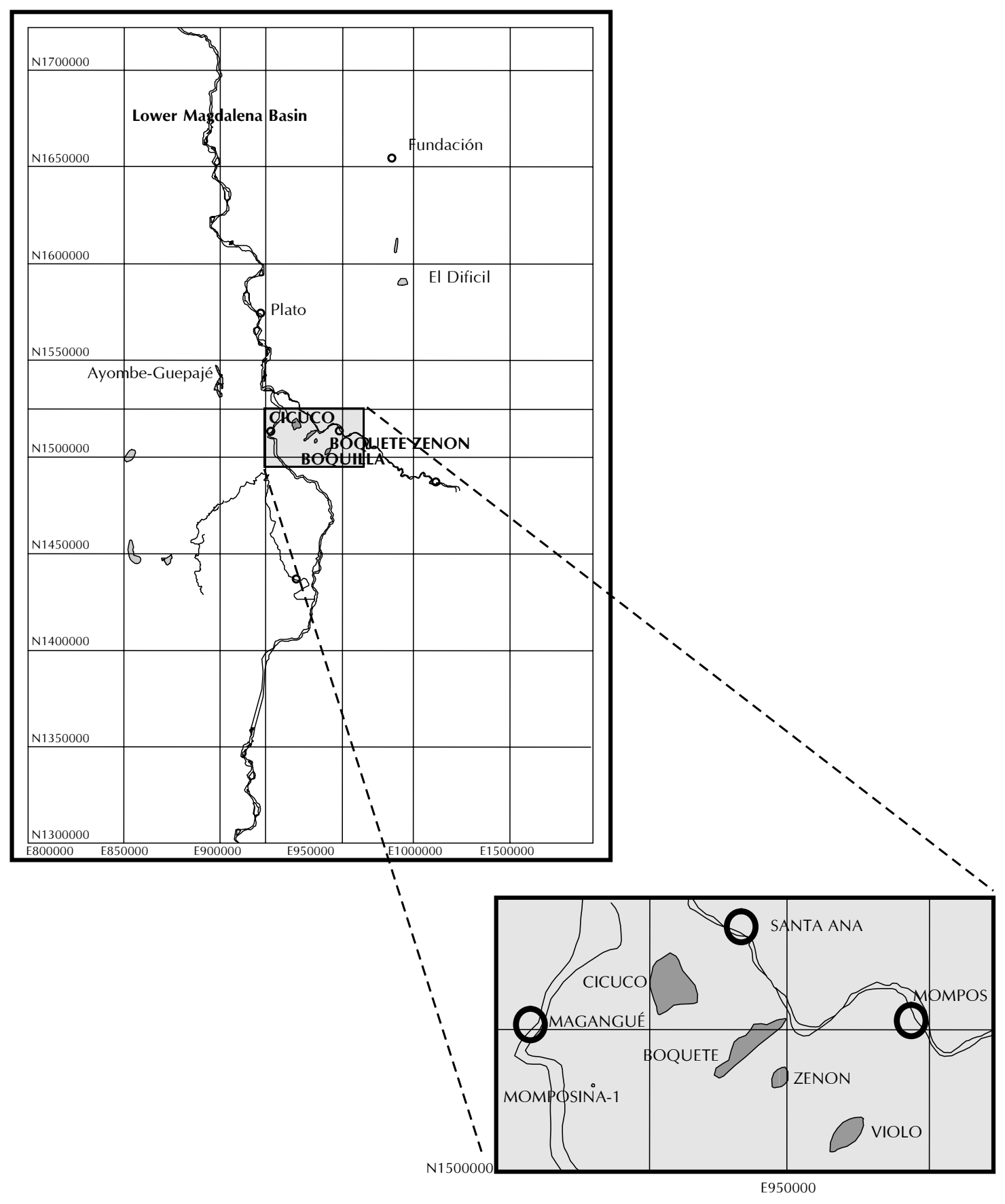

Figure 1. Study area location 
The objective of this study is to evaluate the geochemical characteristics of the the Cicuco-BoqueteViolo area, focused on assess petroleum potential, identify possible compartments inside the production area; infer migration pathways and recognize exploration opportunities. Based on this objective some specialized geochemical analyses were performed, and the geochemical information from previous regional studies was reinterpreted.

It should be pointed out that the Cicuco Field was discovered in the 1950's, and produces from the operational unit named "Calizas de Cicuco", at an approximate depth of 8000 feet. To date, 28 wells have been drilled inside the Cicuco Field, of which six remain active, with an accumulated production of 44,69 MBO and 184,14 GCFG (through Jun/2000). The Boquete Field, $9 \mathrm{~km}$ Southeast of the Cicuco Field, began to operate in 1961. The development of this field demanded the drilling of 24 wells. The accumulated production is $18,18 \mathrm{MBO}$ and 38,67 GCFG (through Jun/2000). Currently, nine wells are still active.

\section{GEOLOGICAL FRAMEWORK}

The "Concession Cicuco-Violo" area has an extension of 50000 hectares. It is located in the Southeastern end of the Lower Magdalena Valley Basin (LMVB), in the Plato Sub-basin (Figure 1).

This region is a stable platform overlaying a continental crust. The Cretaceous sediments are absent and a thick Tertiary sedimentary sequence rests on Lower Cretaceous igneous metamorphic basement (Figure 2).

The LMVB at the Oligocene is characterized by a tectonic extension originated from a normal rotational

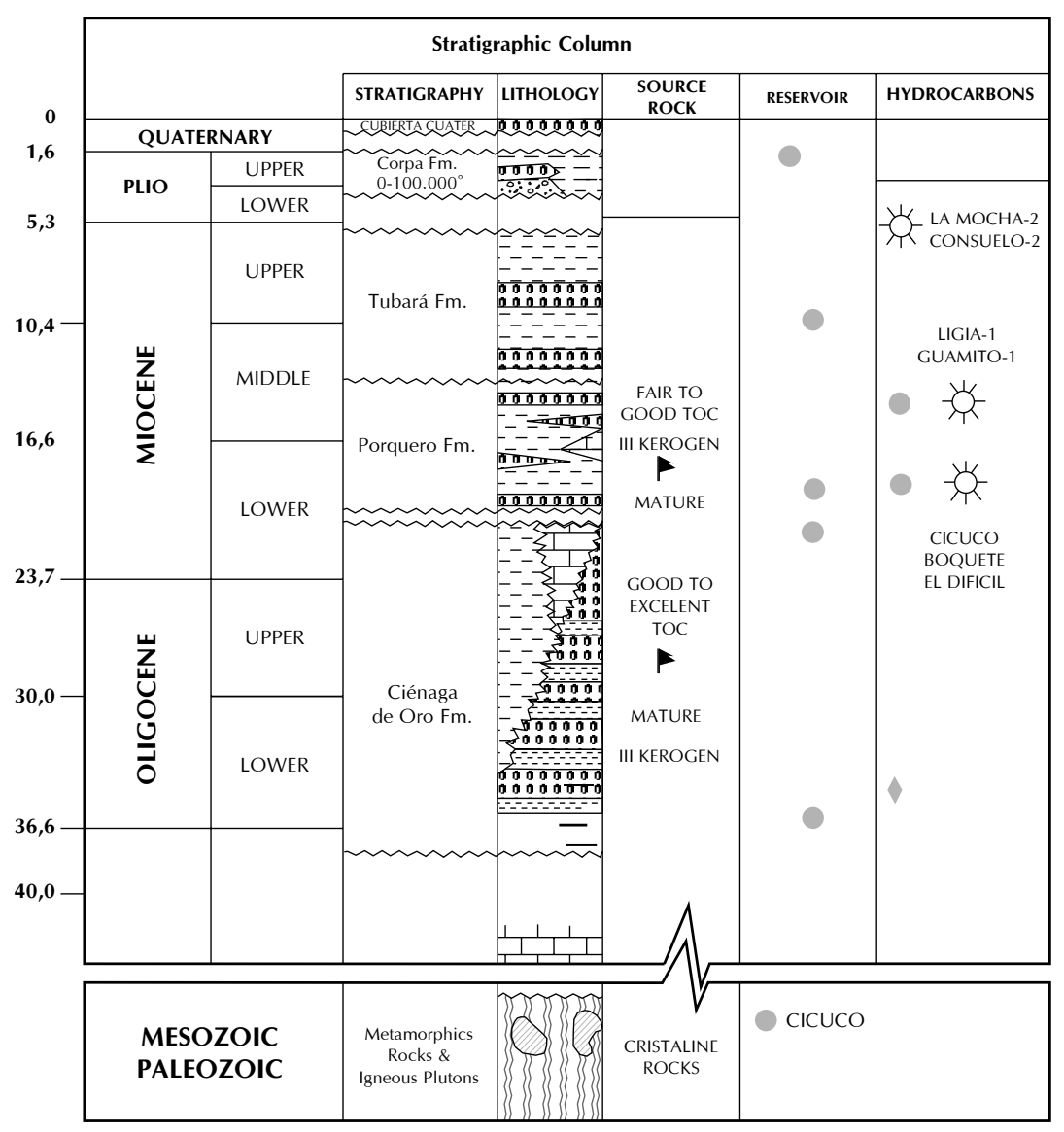

Figure 2. Generalized stratigraphical column, El Plato Basin, VIM 
faulting and a Horst and Graben complex (González, 2000). The origin of the Plato and San Jorge sub-basins is explained by clockwise rotational movements of the block framed by the Bucaramanga, Oca, and Perijá faults, possibly since the Upper Eocene.

The Plato basin is considered to be a stable region whose series of vertical faults originated a "horst and grabens" tectonic style. The Oligocene to the recent sedimentary sequence (Ciénaga de Oro, Porquero, Tubará, and Corpa Formations) was deposited upon a Lower Cretaceous igneous metamorphic basement. The main structural features include the Alejandría, Apure, Magangué, and Cicuco paleo-highs, and the predominance of a normal faulting NE-SW that affects the crystalline basement as well as the Tertiary sequence.

The Tertiary sedimentary sequence consists of three depositing cycles (Mora, 1988; Ingeominas, 1994). The first, Upper Eocene-Lower Miocene, correspond to the Ciénaga de Oro Formation; the second, Lower to Medium Miocene, has been called Porquero Formation; and the third is the Tubará Formation. Overlaying these sequences rests the Corpa Formation and the Quaternary deposits left by the Magdalena River.

The Ciénaga de Oro Formation (Lower OligoceneMiocene) extends across the entire Plato Subbasin. It mainly consists of sandstone and limestone (in the zone corresponding to the Cicuco, Boquete, Zenón, Boquilla, and Violo fields), and lutites (between the Cicuco and the El Dificil paleo-highs).

The deposition environment for the calcareous sequence corresponds to an accretionary shelf margin with reefs and/or calcareous sand bodies (skeletal or oolitic) along the platform's rim. The platform's rim is a turbulence and a high-energy zone; with possible high organic productivity according to Tucker (1992). The lutite facies to the north of the studied fields are interpreted as an external neritic environment (Ortíz and Niño, 1999).

The Porquero Formation (Lower to Middle Miocene) consists of deeper-water shales and sandstones, deposited during a period of rapid subsidence (external neritic environment to upper batial).

The Tubará Formation (Middle Miocene to Lower Pliocene) is a sequence of shales and platform sand- stones (Chevron, 1986). The Corpa Formation (Pliocene) consists primarily of gray claystone with thin levels of gray limestone and sporadic levels of limestone. (Mora, 1988).

\section{METHODOLOGY}

The Gas Chromatography is a well-established technique for the characterization of crude oils (Tissot and Welte, 1981). The gas chromatographic analyses and their interpretation performed in this study were carried out following the method described by Kaufman et al. (1987 and 1990). For reservoir continuity, the $\mathrm{GC}$ fingerprints are examined in detail in order to discover subtle differences among isoalcanes, naphthenic and aromatic compounds. The chromatograms represent over 500 measurable peaks and only small number of these has been matched to specific compounds. Therefore numbers identifies peaks. Peaks selected for correlation are normalized by calculation of peak height ratios. The ratios are calculated from adjacent or very close peaks. Gas chromatography are very reproducible when operating conditions are carefully controlled. Correlations of chromatographic fingerprints were done using statistical methods such us multivariate statistical grouping, or simple graphical comparison in star diagrams. Differences between oils groups can be interpreted in terms of geologic processes and alteration mechanism.

\section{RESULTS AND DISCUSSION}

\section{Petroleum source rocks}

\section{Source rocks}

The Oligocene-Miocene sequences, in particular the Ciénaga de Oro and Porquero formations, constitute the hydrocarbon-generating source rocks in the basin (Reyes et al., 1998; Rangel, 1999).

The Ciénaga de Oro Formation has an upper interval with fair-to-rich contents of organic matter, Type-III, in oil window maturity towards the deepest sectors of the basin (Guamito-1, Ligia-1 and Pijiño-1 wells) (Reyes et al., 2000; Rangel, 1999). This interval is a clayey deposit developed in a maximum flooding event. 
The Porquero Formation (Lower to the Middle Miocene age), exhibits poor to good contents of organic matter, Type-III, immature (Tmax $\left.<436^{\circ} \mathrm{C}\right)$. In some areas of the sub-basin (Ligia-1, Pijiño-1, Apure-1 and Apure-2 wells), this formation is at the begin of the oil window, with Tmax around $430^{\circ} \mathrm{C}$ (Reyes et al., 2000; Rangel, 1999). These data suggest marginal conditions for hydrocarbon generation. Regarding the geological environment, the lower interval corresponds to a submarine fan deposits, and the upper interval is a shallower environment deposits, which are interpreted as upper batial to external neritic, according to the bioestratigraphic analysis (González, 2000).

\section{Effective-source rock pods}

The trends of quality, quantity and maturity parameters of the upper interval of the Ciénaga de Oro Formation indicate good hydrocarbon potential. The maturity indicates effective hydrocarbon source rock towards the center-south of the Plato Basin (Rangel, 1999).

According to the observed trends, in the upper interval of the Ciénaga de Oro Formation, the TOC contents increase towards the Southeast and Southwest sectors of the Plato Subasin where the Hydrogen indices indicates the presence of Type-III kerogen. Upon maturation, the maturity increases to the south-central part of the Plato Basin, where burial depths of the Ciénaga de Oro are at the maximum.

The available source rock data suggest a hydrocarbon source rock pod, coinciding with the area with greater depths section of sediments. This area is located between the Apure-2X, El Castillo-1, Pijiño-1 and Flor del Monte1 wells (Figure 3). It is expected that the deeper section of the Ciénaga de Oro Formation is in zone of gaseous hydrocarbon generation and had expulsed oil and gas.

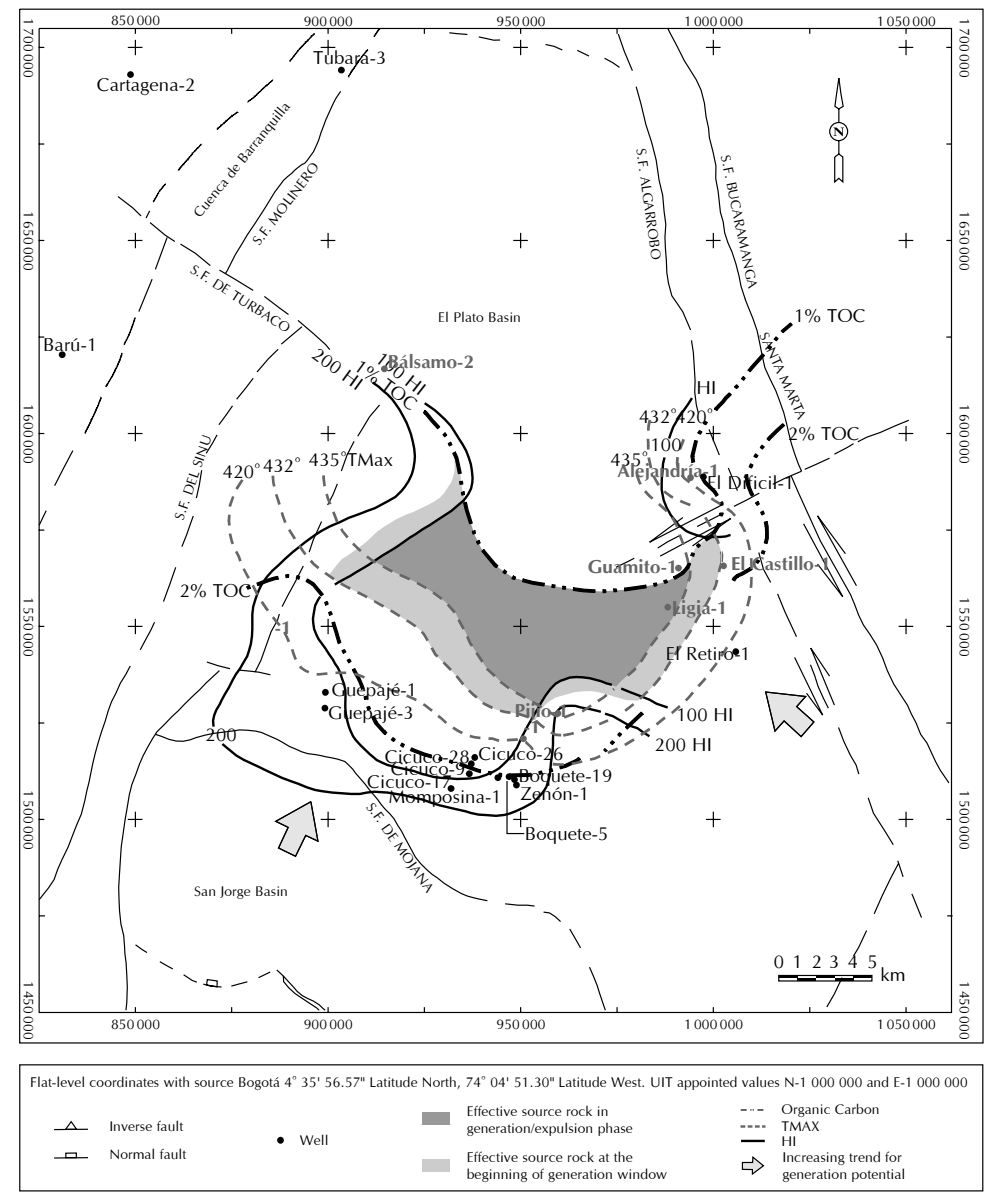

Figure 3. Effective source rock pods 


\section{Geochemistry of oils}

\section{General characteristics}

API gravity varies between $30,9^{\circ}$ and $52,4^{\circ}$. The highest value $\left(52,4^{\circ}\right)$ corresponds to the Momposina-1 crude oil. The sulfur contents are very low, ranging from 0,01 to $0,1 \mathrm{wt} \%$, while the paraffin concentration is relatively high, exceeding $70 \%$ and up to $80 \%$
(Table 1), indicating light crude oils originated from organic matter deposited in a marine proximal environment (Rangel, 1999).

\section{Sedimentary environment as inferred from crude oil composition}

Various geochemical parameters indicate that the majority of oils originated in a relatively disoxic, proxi-

Table 1. Studied wells featuring certain general and biomarkers-related data

\begin{tabular}{|c|c|c|c|c|c|c|c|c|c|}
\hline Well & Interval & $\begin{array}{l}\text { Analytical } \\
\text { Phase }\end{array}$ & ${ }^{\circ} \mathrm{API}$ & $\begin{array}{l}\text { Sulphur } \\
\text { (\%) }\end{array}$ & $\begin{array}{l}\text { Diasterane/ } \\
\text { Sterane }\end{array}$ & $\begin{array}{c}\mathrm{C}_{35} / \mathrm{C}_{34} \\
\text { Hopanes }\end{array}$ & $\begin{array}{l}\mathrm{C}_{24} \mathrm{Te} / \\
\mathrm{C}_{26} \text { Tri }\end{array}$ & $\begin{array}{l}\mathrm{C}_{23} \text { Tri/ } \\
\mathrm{C}_{30} \mathrm{Hop}\end{array}$ & $\begin{array}{l}\text { Oleanane/ } \\
\mathrm{C}_{30} \text { Hopane }\end{array}$ \\
\hline Cicuco-2 & 7843-7922 & Phase I & 44 & 0,0 & 3,70 & 0,43 & 1,54 & 3,70 & 1,00 \\
\hline Cicuco-3 & $7964-8418$ & Phase II & 44 & 0,0 & 5,07 & 0,66 & 1,83 & 3,26 & 0,91 \\
\hline Cicuco-4 & $7795-8215$ & Phase I & 39 & 0,0 & & & & & \\
\hline Cicuco-5 & $7942-8275$ & Phase II & 41 & 0,0 & 4,56 & 0,48 & 5,63 & 0,97 & 0,40 \\
\hline Cicuco-6 & $8032-8316$ & Phase II & 38 & 0,1 & 4,91 & 0,50 & 1,50 & 2,95 & 0,97 \\
\hline Cicuco-8D & $8718-8846$ & Phase I & 39 & 0,1 & 4,12 & 0,55 & 1,46 & 3,42 & 0,99 \\
\hline Cicuco-15D & $8019-8411$ & Phase II & 46 & 0,0 & 5,26 & 0,54 & 1,50 & 3,45 & 0,96 \\
\hline Cicuco-18D & $8085-8442$ & Phase II & 34 & 0,1 & 4,68 & 0,49 & 1,54 & 3,20 & 0,99 \\
\hline Cicuco-19D & $8420-8630$ & Phase II & 39 & 0,1 & 4,57 & 0,56 & 1,84 & 3,15 & 0,95 \\
\hline Cicuco-22 & $8076-8207$ & Phase I y II & 41 & 0,0 & 3,53 & 0,57 & 1,74 & 3,93 & 1,00 \\
\hline Boquete-3 & $8029-8245$ & Phase II & 40 & 0,1 & 8,39 & 0,50 & 1,98 & 2,97 & 0,73 \\
\hline Boquete-5 & $8016-8241$ & Phase II & 41 & 0,1 & 4,51 & 0,56 & 1,75 & 2,89 & 0,67 \\
\hline Boquete- 7 & $7825-8266$ & Phase II & 31 & 0,1 & 3,89 & 0,65 & 0,82 & 3,87 & 0,75 \\
\hline Boquete- 8 & $7960-8390$ & Phase II & 36 & 0,1 & 4,74 & 0,55 & 1,80 & 3,13 & 0,95 \\
\hline Boquete-9 & 7877-8219 & Phase I & 33 & 0,1 & 3,81 & 0,54 & 1,55 & 3,29 & 0,96 \\
\hline Boquete- 10 & $7871-8288$ & Phase II & 43 & 0,1 & & & & & \\
\hline Boquete- 11 & 7898-8102 & Phase I & 41 & 0,1 & 3,94 & 0,57 & 1,62 & 3,39 & 1,00 \\
\hline Boquete-12 & $7783-8190$ & Phase I & 36 & 0,1 & 3,52 & 0,59 & 1,64 & 3,55 & 0,98 \\
\hline Boquete- 14 & $7754-8214$ & Phase II & 39 & 0,1 & & & & & \\
\hline Boquete- 16 & $7925-8479$ & Phase II & 43 & 0,0 & 4,98 & 0,68 & 1,57 & 3,15 & 0,95 \\
\hline Boquete-17 & $7695-8154$ & Phase I & 40 & 0,1 & 3,66 & 0,57 & 1,54 & 3,48 & 1,00 \\
\hline Boquete-23 & $7970-8306$ & Phase II & 35 & 0,1 & 4,53 & 0,49 & 1,76 & 3,06 & 0,94 \\
\hline Momposina-1 & $7940-8082$ & Phase I y II & 52 & 0,0 & 3,47 & 0,87 & 1,26 & 4,75 & 0,84 \\
\hline Boquilla-2 & & Phase II & 31 & 0,1 & 6,61 & 0,50 & 1,65 & 3,46 & 1,09 \\
\hline Boquilla-6 & & Phase II & 31 & 0,1 & & & & & \\
\hline Zenón-1 & $6288-6422$ & Phase II & 40 & 0,1 & & & & & \\
\hline
\end{tabular}


mal siliciclastic environment. For example, the $\mathrm{C}_{35} / \mathrm{C}_{34}$ homohopane ratios are low, (close to 0,5 ); the regular diasteranes/steranes ratios are high, generally greater than 3; and the $\mathrm{C}_{24}$ tetracyclic are generally abundant. According to Mello et al. (1988), the diasteranes/steranes ratio is commonly used to distinguish between carbonate sourced oil versus siliciclastic sourced oil. On the other hand, Moldowan $(1985,1986)$ points out that the concentration of diasteranes reflects the oxicity of the environment, as well as the presence of clay minerals. Mello et al. (1988), and Philp and Gilbert (1986) indicate that the abundance of $\mathrm{C}_{24}$ tetracyclic may be an input marker for higher plant biomass.

Oleanane is present in very high concentrations (oleanane/hopane ratios close to 1). Oleanane is known as a biomarker originated from higher plants (Ekweozor, 1981), which also limits the source-rock age to the Tertiary or Upper Cretaceous and a proximal depositional environment. Moldowan et al. (1994) suggested that an oleanane index above 0,3 is an indication of crude oils derived from rocks of tertiary age. According to the aforementioned, crude oils from the Cicuco-Boquete area originated in a proximal marine environment of Tertiary age (Figure 4). On the other hand, biomarkers and the abundance of alcanes of lower molecular weight show a maturity range relating to middle oil window. The level of maturity is near the end of the crude oil generation window, or at the beginning of the gas generation window. Hydrocarbons expected from these locations would be mainly light crude oil, condensed, and gas.

\section{Crude oil - source rock correlations}

Distribution of biomarkers from the Guamito-1 and Danta-1 wells at the Ciénaga de Oro Formation is relatively similar to that of crude oils from the CicucoBoquete fields (Figures 4 and 5). Graphic comparison of organic matter and depositional environment indicators in crude oils and rocks (Figures 4 and 5) show a certain degree of similarity, indicating that crude oils are derived from a less oxic-siliciclastic sector of the Ciénaga de Oro Formation

\section{Oilfield geochemistry \\ Groups of crude oils}

The results of the crude oil chromatographic analysis, as illustrated in star diagrams, show significant differences among the oils. These plots are based on the alcane distribution between the $n-C_{9}$ to $n-C_{29} n$-alkanes and selected compound ratios among these peaks.

The chromatographic analyses were run in two batches at different times and they are presented in separated star diagrams (Figure 6). The star diagrams
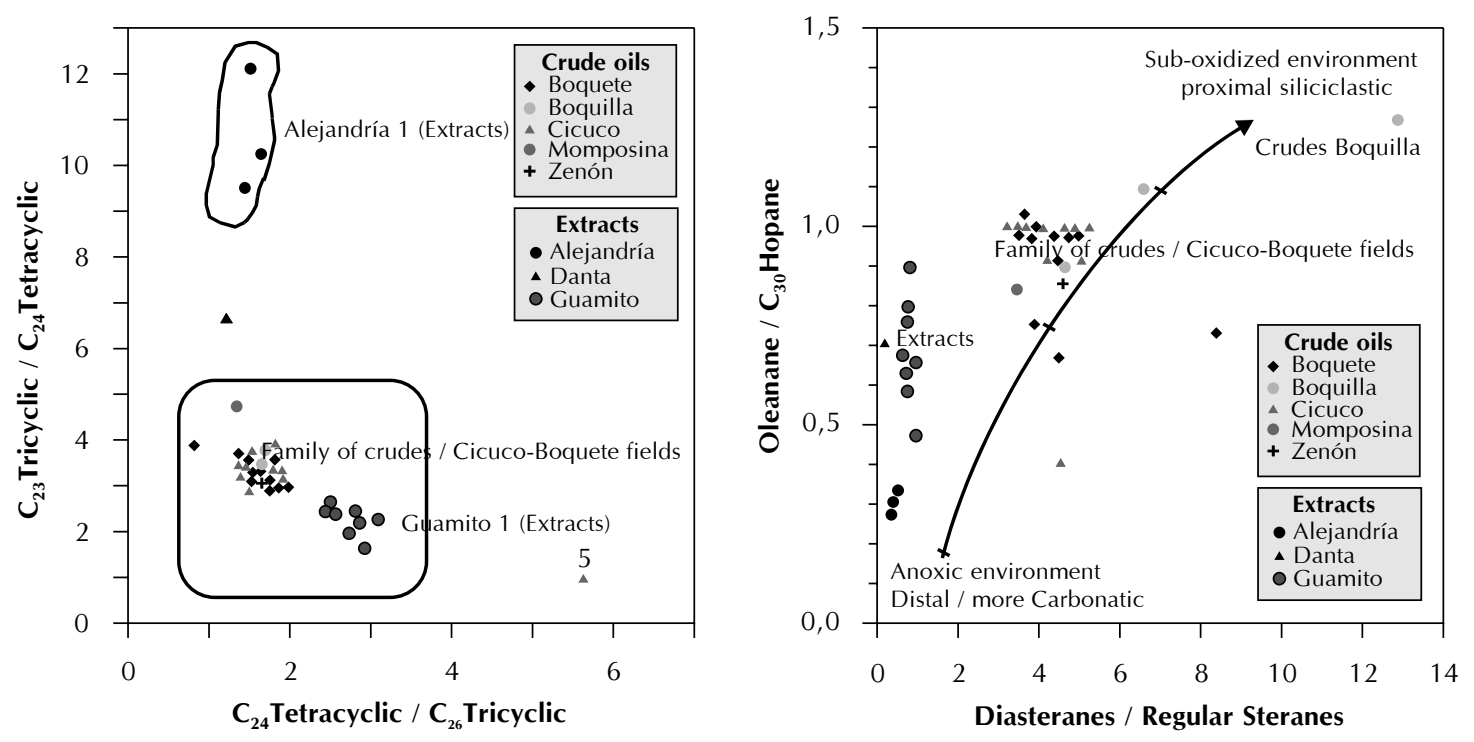

Figure 4. Correlation based on sedimentary environment indicator parameters. Oils and Extracts - El Plato Basin 

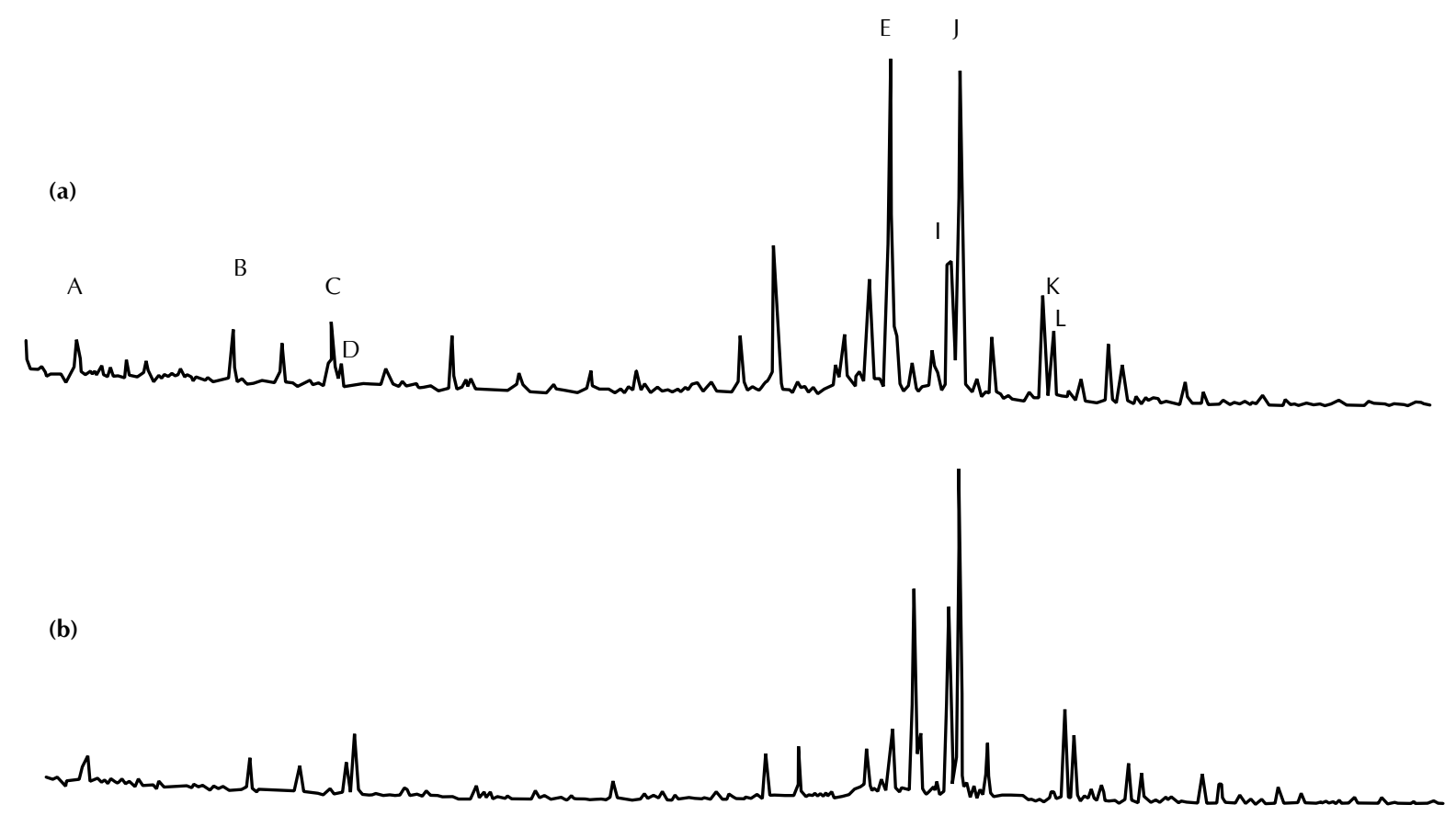

$$
\begin{array}{ll}
\text { H } & \mathrm{C}_{29} 17 \mathrm{a}(\mathrm{H}), 21 \mathrm{~b}(\mathrm{H}) \text { - Norhopane } \\
\text { I } & \mathrm{C}_{30} 18 \mathrm{a}(\mathrm{H}) \text { Oleanane } \\
\text { J } & \mathrm{C}_{30} 17 \mathrm{a}(\mathrm{H}), 21 \mathrm{~b}(\mathrm{H}) \text { - Hopane } \\
\text { K } & \mathrm{C}_{31} 17 \mathrm{a}(\mathrm{H}), 21 \mathrm{~b}(\mathrm{H}) \text { - Homohopane }(22 \mathrm{~S}) \\
\text { L } & \mathrm{C}_{31} 17 \mathrm{a}(\mathrm{H}), 21 \mathrm{~b}(\mathrm{H}) \text { - Homohopane }(22 \mathrm{R}) \\
\text { O } & \mathrm{C}_{35} 17 \mathrm{a}(\mathrm{H}), 21 \mathrm{~b}(\mathrm{H}) \text { - Pentaomohopane }(22 \mathrm{R})
\end{array}
$$

Figure 5. Hopane fragmentogram comparison (m/z191). Extract crude-oils Guamito-3 (a) and crude-oil Cicuco-5 (b)

show differences between the oils of the Boquilla Field and the Momposina-1 well, suggesting lack of communication between both reservoirs. The Cicuco, Boquete, and Zenón oil fields, show some differences (Figure 6), which may be related to structural or stratigraphic barriers. These should to be evaluated in context of the oilfield's geology.

The clustering diagram shows a high correlation factor (greater than 0,85) for the Cicuco, Boquete and Zenón oils. Nevertheless, it should be pointed out that the Boquete and Cicuco oils show some differences among themselves, which should be examined.

\section{The Boquete Field}

Evaluations of the star diagrams (Figure 6) allow differentiation of five subgroups among the Boquete Field crude oils:
- Subgroup-1: Boquete-8, Boquete-5, and Boquete23 (SB1).

- Subgroup-2: Boquete-7, Boquete-14, and Boquete16 (SB2).

- Subgroup-3: Boquete-11, Boquete-12, and Boquete-17 (SB3).

- Subgroup-4: Boquete 9 (SB4).

- Subgroup-5: Boquete 10 (SB5).

These groups allow inferring the presence of a migration barrier, possible faulting between subgroups SB-1 and SB-2. Similarly, geology data also reveal differences that might be correlated to possible stratigraphic or structural discontinuities between the subgroups SB2 and SB5 as well as between the subgroup SB3 and the subgroup SB4. 

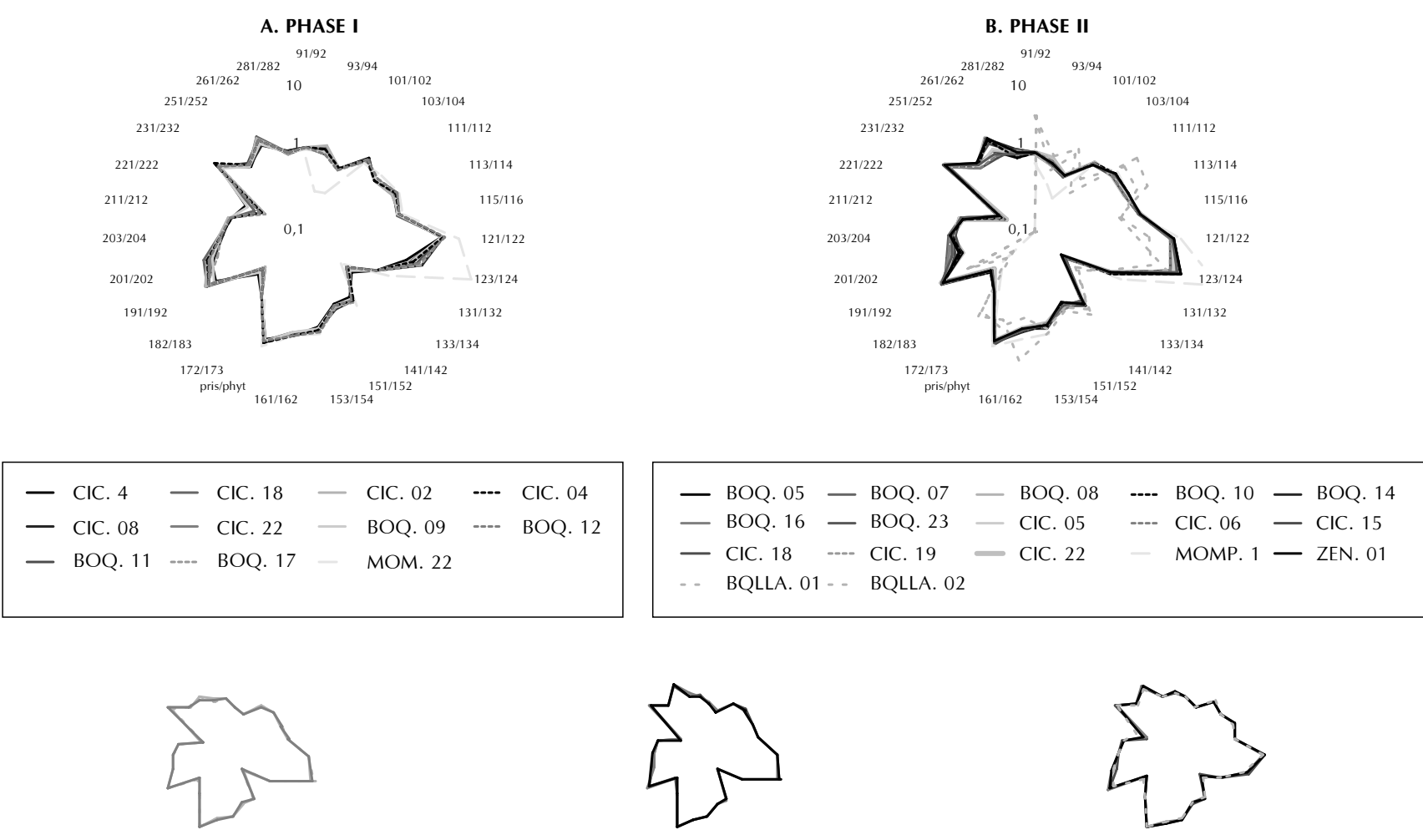

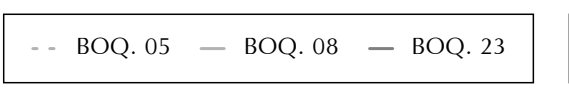

Boquete-5, 8 and 23 (SB-1)
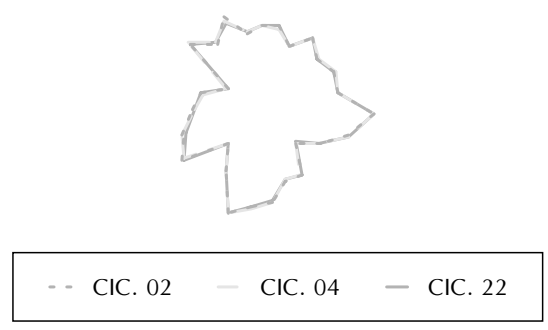

CIC. 2, 4 and 22 very similar among each other (SC-2)

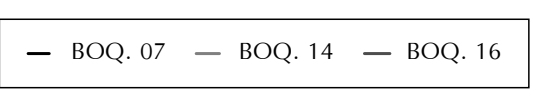

BOQ. 07, 14 and 16 very similar each other (SB-2)
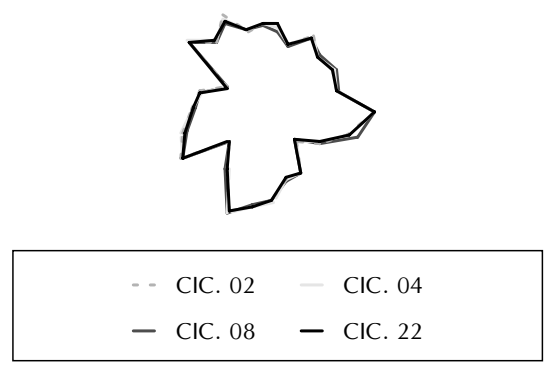

CIC. 8 (SC-3) shows differences with $\mathrm{CIC} .2,4$ and 22 (SC-2)

Figure 6. Crude-oil groups based on the stardiagram matching 
It should be noted that towards the southern part of the Boquete Field area, the crude oil fingerprints reflect discontinuities, possible stratigraphic, which require a more detailed discussion beyond the scope of this study. However, in very general terms, the Spontaneous Potential, Gamma Rays and Sonic Potential logs show similar tendencies, with only a minor increment in the Gamma Ray values in the SW-NE direction. In this context, the sequence become finer, less porous and may form a seal.

\section{The Cicuco Field}

When comparing the star diagrams for the Cicuco area, it is possible to idenfify the following subgroups (from North to South) within the Cicuco Field:

- Subgroup-1: Cicuco-05, Cicuco-06 and Cicuco-18 (SC-1).

- Subgroup-2: Cicuco-19, Cicuco-02, Cicuco-04, and Cicuco-22 (SC-2).

- Subgroup-3: Cicuco-8 (SC-3).

- Subgroup-4: Cicuco-15 (SC-4).

Crude oils form the Cicuco-5 and Cicuco- 6 and Cicuco-18 correlate, allowing them to be classified as an independent subgroup (subgroup SC-1). In turn, there is a great similarity between crude oils from the Cicuco-19 and Cicuco-22 wells; therefore, they are classified as subgroup SC-2 (Figure 6). The main difference between these two subgroups is observed in the $203 / 204$ to $261 / 262$ peak ratios and may be attributed to stratigraphic or structural discontinuity.

Crude oils from the Cicuco-2, Cicuco-4, and Cicuco-22 wells show very good correlation, enabling them to be correlate as subgroups SC-2. These, in turn show important differences in the 123/124 and 201/ 202 peak ratios with crude oil from the Cicuco-8 well, classifying the latter as subgroup SC-3 (Figure 6). The crude oil from Cicuco-15, shows important differences when compared to the other subgroups, therefore, it has been classified as Subgroup SC-4. Cicuco-8 also shows significant differences when compared to the Cicuco Field crude oils. Some stratigraphic and/or structural complexity could be nominated between crude Cicuco15 and Cicuco-8.

\section{Structural control on geographical crude-oil distribution}

In order to evaluate the control exerted by faults in the distribution of the oil groups, they were mapped on a structure map, at the top of the main productive unit, the Calizas de Cicuco Formation (Figure 7).

In the Boquete Field, the distribution of certain crude oil groups shows a good match with the distribution of faults and with the predominant structural style. Other groups are possibly restricted by stratigraphic-type barriers. In the case of structural reservoir discontinuities, normal faults perpendicular to the main faulting (Boquete Fault) seems to be the crude-oil diffusion barrier. Barriers by stratigraphic discontinuity are found in the middle part of the monoclinal of the Boquete field (lesser-stress zone) (González, 2000).

In the Cicuco Field, the predominant barriers are stratigraphic. The borders for the oil groups appear to be the less fractured zones located in the dome of the Cicuco structure (i.e. the zone less affected by stress).

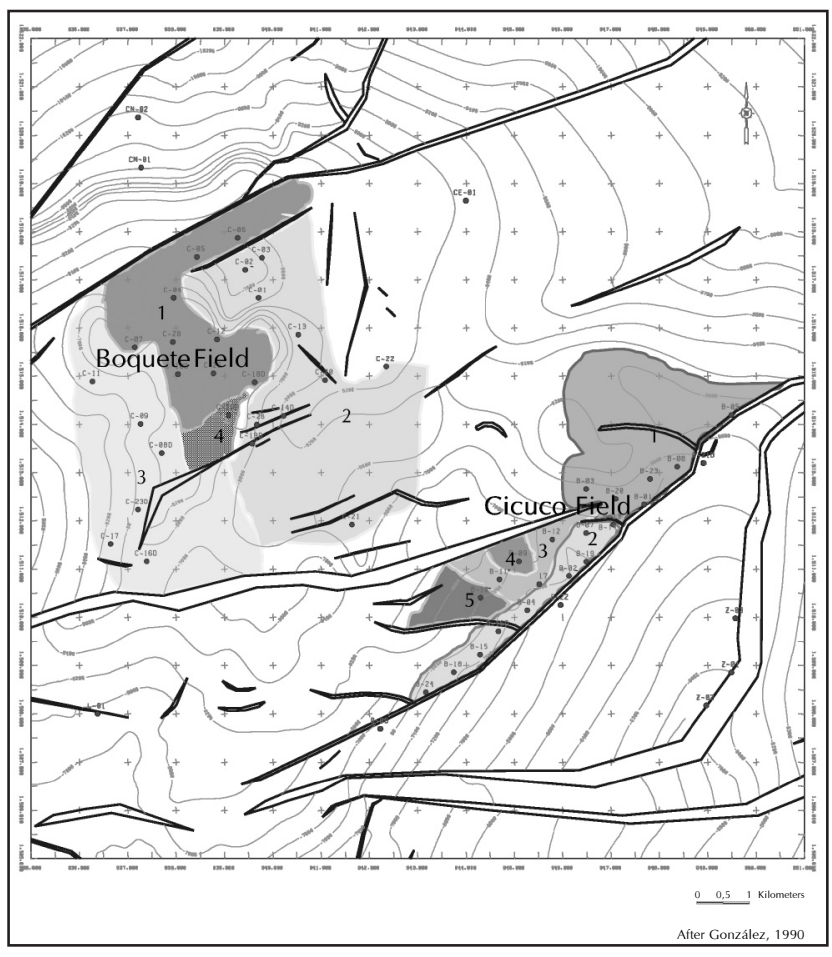

Figure 7. Distribution of crude oil sub-groups in the Cicuco-Boquete fields. The distribution obeys structural barriers and stratigraphic discontinuites 


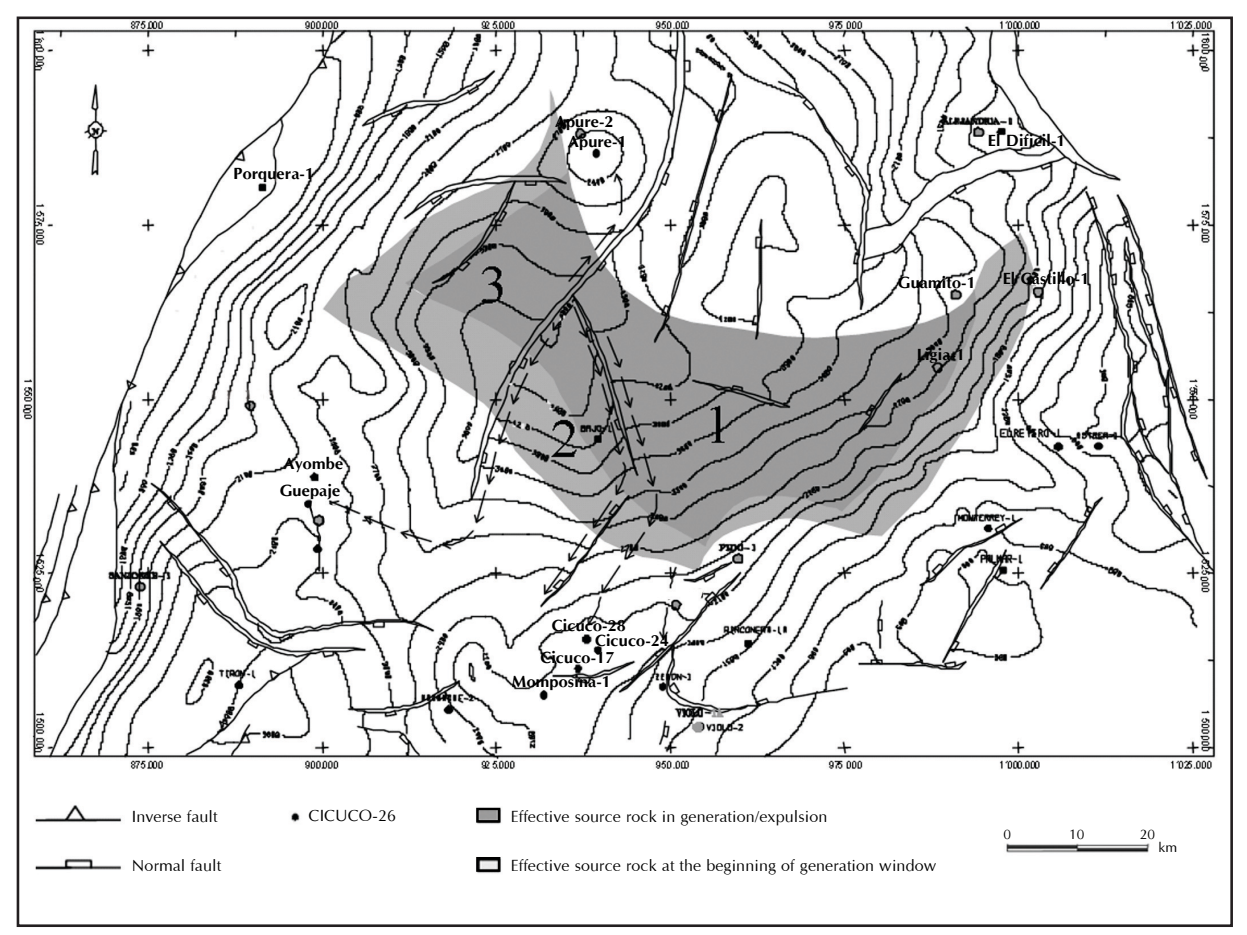

Figure 8. Distribution of crude-oil sub-groups in the Cicuco-Boquete fields. This distribution is based on structural-type barriers and stratigraphical discontinuities

\section{Migration routes}

Effective source-rock pod were defined in the upper interval of the Ciénaga de Oro Formation, within the area of Apure-1 and Apure-2 wells (Northwest), Flor del Monte well (Southwest), Pijiño-1 well (South), and El Castillo-1 well (East) (Figure 8). The source rock pod is structurally compartmentalized into at least three migration zones related to the main faulting tendencies: Southwest-Northeast and Northwest-Southeast.

Four main migration pathways starting at the drainage zones are proposed, such that they might explain the accumulations in:

1. The Cicuco-Boquete field area.

2. The Momposina-2 well area, and possible structures in this drainage pathway.

3. Ayombe-1 and Guepajé-1 well areas.

4. The Apure-1 and Apure-2 well areas, and other possible structures in this drainage pathway.

As for the Cicuco-Boquete field, its hydrocarbons originate from drainage zones 1 and 2 . The majority of the crude oil volume was possibly channeled by a Northwest-Southeast fault that seems to be a barrier inside the source rock pod, channeling the crude oil towards the area limited by the Cicuco and Boquete faults. The lowest risk would be related to the structures located between the generation pod and the known Cicuco-Boquete accumulations. Accordingly, it is suggested that possible structures located inside the migration route be evaluated, especially between the wells located toward the Northernmost area of the Cicuco-Boquete field and the generation pod.

A second migration route (Northwest-Southeast), related to drainage zone number 2, is proposed beginning along the Los Alpes fault; and later, NortheastSouthwest, along the Cicuco North fault. This fault is interpreted as a migration route, directing crude oils towards the Momposina-1 well. The drainage zone \#2 is associated to rocks deeper than zone \#1; therefore, a higher yield of gaseous hydrocarbons should be expected in this migratory pathway. The Yatí-1 and Tacamocho-1wells are located along this migration route. The historical reports for these two 
wells do not show evidence of either gas or oil. This situation worthy of re-evaluation in light of the reservoir effectiveness, since, a hydrocarbon migration pathway existed in this area according to this study. The presence of crude-oil impregnations in the cores and cuttings should be examined. Additionally, a third migration route is associated to drainage zone \# 2 , linked to the accumulations in the Ayombe- 1 and Guepajé-1wells

The drainage zone \# 3 might be expulsing hydrocarbons towards structures nearly the Apure-1 and Apure-2 wells sector. Reference is made to these structures, so as to suggest the probability of new prospects.

It is suggested that possible structures located along the proposed four migration routes be evaluated, especially these areas located between the described pod of generation and the accumulation areas discussed in this study.

\section{CONCLUSIONS}

\section{- Hydrocarbon Generating Zones}

The upper interval of the Ciénaga de Oro Formation is a hydrocarbon-generation section in the central area of the Plato Sub-basin, which extends between the Apure-1 and Apure-2 (Northeast), Flor del Monte-1 (Southwest), Pijiño-1 (South), and El Castillo-1 (East) wells.

\section{Crude-oil}

One single family of crude oils exists, originated in rocks from a proximal marine environment of Tertiary age.

\section{- Crude oil-rock correlations}

Ciénaga de Oro Formation extracts from the Guamito-1 and Danta-1 show a fairly good correlation with crude oils from the Cicuco-Boquete fields.

\section{Reservoir connectivity}

Crude oil from the Momposina-1 well and crude oils from the Boquilla field are separate reservoirs.

Crude oils from the Boquete area may be separated into the following subgroups, from North to South:
- Subgroup SB-1: Boquete-8, Boquete-5, and Boquete-23.

- Subgroup SB-2: Boquete-7, Boquete-14, and Boquete-16

- Subgroup SB-3: Boquete-11, Boquete-12, and Boquete-17

- Subgroup SB-4: Boquete 9

-Subgroup SB-5: Boquete 10

The presence of subgroups SB1 and SB2 is compatible with the existence of a structural barrier between the subgroups, possibly Northeast-Southeast, and perpendicular to the Cicuco Fault.

Correlations among Subgroups SB-2, SB4, and SB5 might correspond to a structural or stratigraphic barrier.

Crude oils from the Cicuco area may be separated into the following subgroups, from North to South:

- Subgroup SC-1: Cicuco-05, Cicuco-06, and Cicuco-18.

- Subgroup SC-2: Cicuco-19, Cicuco-02, Cicuco-04, and Cicuco-22.

- Subgroup SC-3: Cicuco-8.

- Subgroup SC-4: Cicuco-15.

These subgroups are attributed to stratigraphical and/or structural-type discontinuities.

\section{Drainage zones and migration paths ways}

The proposed generation zone is compartmentalized into at least, three drainage zones related to the two main faulting trends.

Four different migration pathways are proposed, associated to each of the following accumulations: 1) Cicuco-Boquete area, 2) Momposina well area, 3) Ayombe and Guepajé area; and, 4) Apure-1 and Apure-2 wells areas, and other possible structures in this drainage pathway.

\section{New exploration opportunities}

It is suggested that possible structures located along the proposed four migration routes be evaluated, 
especially these areas located between the described pod of generation and the accumulation areas discussed in this study.

\section{ACKNOWLEDGEMENTS}

We are grateful to Ecopetrol S.A. for giving permission to publish this article.

\section{BIBLIOGRAPHY}

Amoco, 1990. "The geology and hydrocarbon potential of the Lower Magdalena Basin, Colombia”. Geologycal Report, 2660 (ISN 17478), Ecopetrol.

Cenpes-Petrobras, 1996. "The petroleum system of the Lower Magdalena Basin, Colombia: a geochemical caracterization of oils and potencial source rocks". Geologycal Report, Ecopetrol.

Chevron Overseas Petroleum Inc., 1986. "Northwest colombia hydrocarbon evaluation”. Geologycal Report, 1406 (ISN 15780), Ecopetrol.

Chevron Overseas Petroleum Inc., 1986. "Geology of the Sinu Basin northwest Colombia”. Geologycal Report, 4855 (ISN 48038). Ecopetrol.

Ekweozor, C. M., Orogun J. I., Ekong, D. and Maxwell, J. R., 1981. "C24-C27 degraded triterpanes in Nigerian petroleum: novel molecular markers of source/input on organic maturation". J. of Geochem. Exploration, 15: $653-662$.

Esri-Ilex Ltda., 1995. “Evaluación geológica regional de la Cuenca del Sinú-San Jacinto”. Informe Técnico, presentado a Ecopetrol, Bogotá.

González, F. S., 2000. “Geología de producción campo Cicuco”. Informe Técnico, Ecopetrol.

Ingeominas, 1994. "Geología de superficie del área de SinúSan Jacinto, Valle Inferior del Magdalena”. Informe Geológico, 3855 (ISN 30941), Ecopetrol.

Kaufman, R. I., Ahmed, A. S. and Elsinger, R. J., 1990. “Gas chromatography as development and production toll for fingerprinting oils from individual reservoirs: aplication in the Gulf of Mexico". GCSSEPM Foundation, Ninth Annual Research Conference Proceedings, 263-282.

Kaufman, R. I., Ahmed, A. S. and Hempkins, W. B., 1987. "A new technique for the analysis of commingled oils and its applications to production allocation calculations". Proceeding Indonesian Petroleum Association, Sixteenth Annual Convention, 246-267.

Martínez, J. F., Luna, O. y Lamilla, J., 1994. “Estado actual del conocimiento de las Cuencas de Plato y San Jorge (Fase II) (Provincia sedimentaria del Valle Inferior del Magdalena)’. Ecopetrol, Bogotá.

Mello, M. R., Telnaes, N., Gaglianone, P. C., Chicarelli, M. I., Brassel, S. C. and Maxwell, J. R., 1988. "Organic geochemical characterization of depositional paleoenvironments in Brazilian marginal basin". Organic Geochemistry, 14: 529-542.

Moldowan, J. M., Dahl, J., Huizinga, B. J., Fago, F. J., Hickey, L. J., Peakman, T. M. and Taylor, D. W., 1994. "The molecular fossil record of oleanane and its relation to angiosperms". Science, 265: 768-771.

Moldowan, J. M., Seifert, W. K. and Gallegos, E. J., 1985. "Relationships between petroleum composition and depositional environment of petroleum source rocks". American Association of Petroleum Geologist Bulletin, 69: 1255-1268.

Moldowan, J. M., Sundararaman, P. and Shoell, M., 1986. "Sensitivity of biomarker properties to depositional environment and/or source input in the Lower Toarcian of S.W. Germany". Organic Geochemistry, 10: 915-926.

Mora, C. A., 1988. "Evaluación geológica de la isla de Mompox”. Informe Interno, Ecopetrol.

Mora, C. A., 1988. "Litofacies de la Fm Ciénaga de Oro en los campos Cicuco-Boquete”. Informe Interno, Ecopetrol.

Ortiz, A. y Niño, H., 1999. “Estudio sedimentológico y estratigráfico de las calizas de Cicuco y Boquete en un sector de la isla de Mompós, Valle Inferior del Magdalena”. Ecopetrol S.A. - ICP.

Philp, R. P. and Gilbert, T. D., 1986. "Biomarker distribution in oils predominantly derived from terrigenous source material". In Leybhaesuer, D., Rullkoter, J. (Eds.), Advances in Organic Geochemistry, 1985. Organic Geochemistry, 10 (1-3), 73-84.

Rangel, A., 1999. "Geoquímica de producción del campo Cicuco-Boquete”. Informe Interno, Ecopetrol.

Reyes, J. P. et al., 2000. “Evalución regional integrada Valle Inferior del Magadalena”. Informe Interno, Ecopetrol.

Tissot, B. P. and Welte, W. H., 1981. "Petroleum formation and occurrence”. New York, Springer Verlag.

Tucker, M. E. and Wright, V. P., 1992. "Carbonate sedimentology”. Blackwell Scientific Publications, London. 